\title{
ミスチューンがある翼・ディスク系のフラッタ解析
}

\author{
金子 康智*1, 竹村 真人 ${ }^{* 2}$, 森 一石 ${ }^{*}$, 大山 宏治 ${ }^{*} 4$
}

\section{Flutter analysis of mistuned bladed disk}

\author{
Yasutomo KANEKO*1, Makoto TAKEMURA ${ }^{* 2}$, Kazushi MORI ${ }^{* 3}$ and Hiroharu OOYAMA ${ }^{* 4}$ \\ ${ }^{*},{ }^{*}$ Department of Mechanical and Systems Engineering, Ryukoku University \\ 1-5 Yokotani, Seta Oe-cho, Otsu-shi, Shiga 520-2194, Japan \\ ${ }^{* 3}$ Mitsubishi Heavy Industries, Ltd. \\ 2-1-1 Shinhama Arai-cho, Takasago-shi, Hyogo 676-8686, Japan \\ ${ }^{* 4}$ Mitsubishi Hitachi Power Systems, Ltd. \\ 2-1-1 Shinhama Arai-cho, Takasago-shi, Hyogo 676-8686, Japan
}

Received 28 September 2014

\begin{abstract}
Although, in designing blades, it is assumed that all blades on a disk are identical (tuned system), the vibration characteristics of the blade is slightly different due to the manufacturing tolerance, the deviation of the material property, and so on (mistuned system). As a result, in the forced response of an actual bladed disk caused by the flow distortion, the responses of all blades become different, and the response of a certain blade may become extremely large, due to the split of the duplicated natural frequencies, the distortion of the vibration modes, and so on. On the other hand, it is suggested by many researchers that the mistuning suppresses the blade flutter, because the complete travelling wave mode is not formed in a disk. In other words, the effect of the mistuning acts on the dangerous side for the forced vibration, while on the safety side for the blade flutter. In this study, the stability analysis of the mistuned bladed disk is carried out using the reduced model with high fidelity, in order to research the effect of mistuning on the blade flutter in detail. In the analysis, the actual bladed disk experienced the blade flutter is analyzed, and the calculated results are compared with the experienced phenomena, to verify the validity of the analysis method.
\end{abstract}

Key words : Turbomachinery, Self-excited vibration, Flutter, Blade, Mistuning

\section{1. 緒言}

翼・ディスク系の振動解析では，通常，ディスク上の全ての翼の特性は同一（チューン系）と仮定されるが， 現実には工作誤差や材料定数のばらつきによって個々の翼の振動特性がわずかに異なっている(ミスチューン系). このため，作動流体の不均一（偏流）に起因する強制応答においては，翼・ディスク連成固有振動数の分化や振 動モードのひずみにより，チューン系に対する共振条件式がもはや成立しなくなり，個々の翼の応答の大きさに 差が現れ，特定の翼のみが大きく応答する．また，チューン系よりも広い周波数範囲に渡って翼が応答するよう になる (金子他, 1992).

一方，チューン系の翼・ディスク系では，フラッタ発生時にはディスク上の全ての翼は同一振幅，かつ一定の 翼間位相差で振動するのに対し，ミスチューン系の翼・ディスク系では明確な進行波や後退波が形成されないた め, 作動流体から翼・ディスク系に供給されるエネルギが小さくなり, フラッタが発生しにくくなる. 寸なわち, ミスチューニングの効果は，強制振動に対しては危険側に，フラッタ（自励振動）に対しては安全側に作用する

No.14-00491 [DOI:10.1299/transjsme.14-00491], J-STAGE Advance Publication date : 20 January, 2015

${ }^{* 1}$ 正員, 龍谷大学 (†520-2194 滋賀県大津市瀬田大江町横谷 1-5)

*2 学生員, 龍谷大学 理工学部

*3 正員，三菱重工業（株）高砂研究所（一 676-8686 兵庫県高砂市荒井町新浜 2-1-1）

${ }^{* 4}$ 三菱日立パワーシステムズ (株)

E-mail of corresponding auhor: y_kaneko@rins.ryukoku.ac.jp 
ことが多くの文献で指摘されている (Kaza and Kielb, 1982, Bendiksen, 1984).

従来，ミスチューン系のフラッタに対する安定性を解析する場合は，翼・ディスク系を単純なば叔・質量系で モデル化していたが，最近はモード領域の低次元モデルを適用した解析が報告されている (Kielb, et al., 2004, Kielb, et al., 2007, Carlos, et al., 2008). このような低次元モデルはミスチューン現象のメカニズムと直結した定式化 をベースにしており, 入力データの作成も容易であるため設計計算に適していると考えられる.

このため, 本研究では低次元モデル FMM を利用した安定性解析法 (Kielb, et al., 2004, Kielb, et al., 2007) を適用 して, 実際にフラッタが発生した蒸気タービンの翼・ディスク系 (日本機械学会編, 2010, Rust, et al., 1988, Nedeljkovic, et al., 1991) の逆解析を行い, 本手法の有効性を検証する.ささらに，ミスチューニングのパターンや 強さ, ディスクの連成効果（構造連成の強さ）, 翼材料などについてパラメータスタディを行い, フラッタに対す るミスチューニングの効果を検討する.

\section{2. 解析方法}

\section{$2 \cdot 1$ FMM によるミスチューン系の固有值解析}

FMM の理論については文献 (Feiner and Griffin, 2002, 2003) に詳しく説明されているので, ここでは要点だけを 記述する. FMM では, 翼・ディスク系のモード族が完全に分離しているとき, ミスチューンがある翼・ディス ク系の着目するモード族の振動モードを, チューン系の当該モード族の振動モードの重ね合わせで式（1）のよう に表す。

$$
\left\{\phi_{r}\right\}=\sum_{m=0}^{N-1} \beta_{r m}\left\{\phi_{m}^{0}\right\}, \quad(r=0, \cdots, N-1)
$$

ここで, $\left\{\phi_{r}\right\}$ はミスチューン系の着目するモード族における $r$ 次の振動モード, $\left\{\phi_{m}^{0}\right\}$ はチューン系の当該モー ド族の $m$ 次の振動モードであり, $N$ は全周の翼枚数である. $\beta_{r m}$ は, ミスチューン系の $r$ 次の振動モードに占め るチューン系の $m$ 次の振動モードの割合を表す係数（ウェィティング）であり, 式 (2) の固有值問題を解くこ とにより求めることができる.

$$
\left(\left[\Omega^{0}\right]^{T}\left[\Omega^{0}\right]+2\left[\Omega^{0}\right][\bar{\Omega}]\left[\Omega^{0}\right]\right)\left\{\beta_{r}\right\}=\omega_{r}^{2}\left\{\beta_{r}\right\}
$$

ここで $\left[\Omega^{0}\right]$ は, チューン系の固有振動数を対角成分にする対角行列であり, チューン系の振動モードをトラ ベリングウェーブモードで表示し翼間位相差が増加する順に振動モードを並べたとき，これに対応する順に固有 振動数を並べている． $\omega_{r}$ はミスチューン系の $r$ 次の固有振動数である.

$[\bar{\Omega}]$ は, ディスク上の個々の翼の振動数分布の離散フーリエ変換を成分にする行列であり, 式（3）のように 表すことができる.

$$
[\bar{\Omega}]=\left[\begin{array}{cccc}
\bar{\omega}_{0} & \bar{\omega}_{1} & \cdots & \bar{\omega}_{N-1} \\
\bar{\omega}_{N-1} & \bar{\omega}_{0} & \cdots & \bar{\omega}_{N-2} \\
\vdots & \vdots & & \vdots \\
\bar{\omega}_{1} & \bar{\omega}_{2} & \cdots & \bar{\omega}_{0}
\end{array}\right]
$$

$[\bar{\Omega}]$ は循環行列であり, その要素 $\bar{\omega}_{p}$ は, 翼単体の固有振動数（着目するモード族の固有振動数）の周方向の 分布を離散フーリエ変換したときの $p$ 番目の成分であり, 式 (4) で表すことができる.

$$
\bar{\omega}_{p}=\frac{1}{N} \sum_{s=0}^{N-1} \exp \left(i s p \frac{2 \pi}{N}\right) \Delta \omega_{b}^{(s)}
$$


ここで, $\Delta \omega_{b}^{(s)}$ はミスチューンにより生じた $s$ 番目の翼の固有振動数の偏差であり, チューン系の翼単体の固 有振動数を $\omega_{b}^{0}$, ミスチューン系の $s$ 番目の翼の固有振動数を $\omega_{b}^{(s)}$ とすると, 式 (5) から求めることができる.

$$
\Delta \omega_{b}^{(s)}=\frac{\omega_{b}^{(s)}-\omega_{b}^{0}}{\omega_{b}^{0}}
$$

すなわち, FMM でミスチューン系の固有振動数と振動モードを計算するために必要な情報は, 着目するモード 族に関するチューン系の固有振動数 $\left[\Omega^{0}\right]$, チューン系の振動モード $\left\{\phi_{m}^{0}\right\}$, およびミスチューン系の翼単体の固 有振動数の分布 $\Delta \omega_{b}^{(s)}$ の三つだけである.これらの情報を入力にして式（3）から式（5）を使用して式（2）の各 要素を計算し, 式 (2) の固有值方程式を解く. その結果, ミスチューンがある翼ディスク系の固有振動数 $\omega_{r}$ と ウェイティング $\left\{\beta_{r}\right\}$ が求まるので， ウェイティング $\left\{\beta_{r}\right\}$ を式（1）に代入して固有モード $\left\{\phi_{r}\right\} を$ 求める. 式 (2) の係数行列の次元は, $N \times N(N$ : 翼枚数 $)$ であり, 自由度を大幅に縮小した固有值方程式を解いて, ミスチュー ンがある翼・ディスク系の固有振動数や振動モードを計算することができる. また，FMM の入力として必要に なるチューン系の固有振動数 $\left[\Omega^{0}\right]$ やチューン系の振動モード $\left\{\phi_{m}^{0}\right\}$ は, 周期対称法を適用すれば 1 セグメント分 だけの自由度に縮小したモデルで解析できる.

\section{$2 \cdot 2$ FMMによるミスチューン系の安定性解析}

翼・ディスク系の減衰は, 一般に材料減衰, 構造減衰, 空力減衰の和になり, トータルの減衰が負になると不 安定振動（フラッタ）が発生するが, 以下の解析では材料減衰や構造減衰の影響は無視し, 空力減衰だけに着目 する. 空力減衰だけを考慮してミスチューン系の安定性を解析する場合には, 式 (2) に流体連成効果を表す非定 常力を追加した式（6）の固有值解析を行い，固有振動数（複素数）を求める.

$$
\left(\left[\Omega^{0}\right]^{T}\left[\Omega^{0}\right]+2\left[\Omega^{0}\right] \bar{\Omega}\left[\Omega^{0}\right]-\omega_{r}^{2}[I]\right)\left\{\beta_{r}\right\}=\left\{F^{m}\right\}
$$

ここで $\left\{F^{m}\right\}$ は作動流体との連成による非定常力，すなわち翼・ディスク系（チューン系）の振動によってフィー ドバックされる非定常力（モーダル外力）であり，式（7）のように表すことができる.

$$
\left\{F^{m}\right\}=\left[A^{m}\right]\left\{\beta_{r}\right\}
$$

ここで $\left[A^{m}\right]$ は影響係数 $a_{n}$ を対角要素にする流体力行列であり, 式（8）のように表すことができる.

$$
\left[A^{m}\right]=\left[\begin{array}{cccc}
a_{0} & & & 0 \\
& a_{1} & & \\
& & \ddots & \\
0 & & & a_{N-1}
\end{array}\right]
$$

式（8）の影響係数 $a_{n}$ は一般には複素数であり， $n$ 節直径の振動モードに対する付加剛性や付加減衰に相当し ており，適当な CFD コードを利用して求めることができる.

式（6）から得られる $j$ 次モードの固有振動数の実部を $\omega_{j R}$, 虚部を $\omega_{j I}$ とすると, 流体力による $j$ 次モードの モーダル減衰比 $\varsigma_{j}$ は式（9）から求めることができる.

$$
\varsigma_{j}=\frac{\omega_{j I}}{\omega_{j R}}
$$


モーダル減衰比 $\varsigma_{j}$ が負であれば空力減衰は負であり, フラッタが発生する.

\section{3. 解析結果}

\section{$3 \cdot 1$ 解析条件}

2 章で説明したミスチューン系の安定性解析法の有効性を検証するため, 実際にフラッタが発生した繁気ター ビンの翼・ディスク系（日本機械学会編，2010, Rust et al., 1988, Nedeljkovic, et al., 1991）の逆解析を行った. 表 1 に, 解析した翼・ディスク系の仕様を示寸. 本翼はチタン製の蒸気タービン L-1R 翼（最終段より 1 段手前の動 翼，単独翼構造）であり，運転開始後 6 日後に全周 120 枚の翼のうち 1 本の翼が翼根から破断し，19 本の翼にク ラックが発生するトラブルを経験している．原因究明のための解析や実機計測を行った結果，高負荷時に発生す るフラッタがトラブルの原因と結論づけている．さらに，対策として交互ミスチューン（隣接する単独翼の振動 数を平均值に対して $2.7 \mathrm{~Hz}$ ずつ交互に変更）を採用し，実機計測を行った結果，フラッタを防止できたことが 示されている.

本翼の逆解析においては．参考文献にキャンベル線図や翼高さなどの基本データは示されているが，翼形状な どの詳細は記述されていないため, 翼・ディスク系の連成振動数などは類似翼の FEM 解析結果から推定してい る. また, 非定常流体力 (CFD 解析結果) については, 文献に記載されている解析結果をそのまま使用している.

図 1(a)に類似翼の FEM 解析結果と参考文献から推定した翼・ディスク系の振動数を示寸. 図中には, 安定性に 及ぼすディスク連成の影響を検討するために使用した Flexible ディスクと Stiffディスクに対する振動数もプロッ トしている．また，図1(b)は安定性解析に使用した非定常空気力であり，図 1(b)の横軸は振動モードの翼間位相 差, 縦軸は対数減衰率で表した空力減衰である.

Table 1 Specification of bladed disk analyzed

\begin{tabular}{|c|c|}
\hline Turbine output [MW] & 700 \\
\hline Material & Ti-6Al-4V \\
\hline Blade height & $406 \mathrm{~mm}(16 \mathrm{in})$ \\
\hline No. of blades/row & 120 \\
\hline Rotation speed [rpm] & 3600 \\
\hline
\end{tabular}

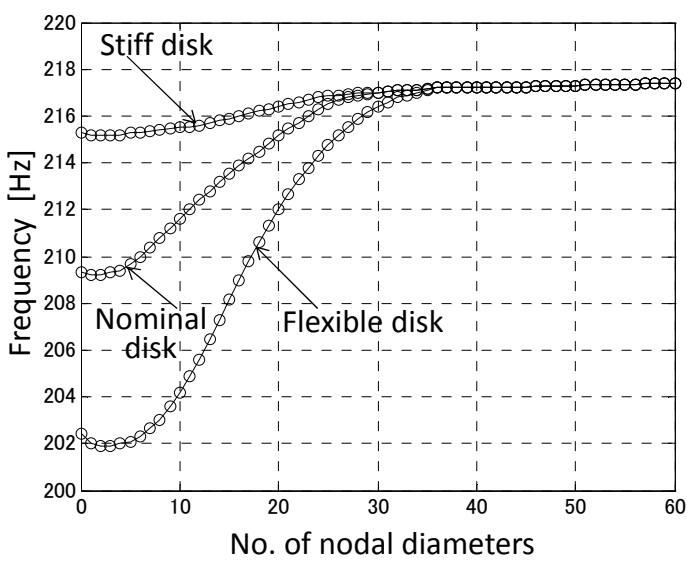

(a) Natural frequency of tuned bladed disk

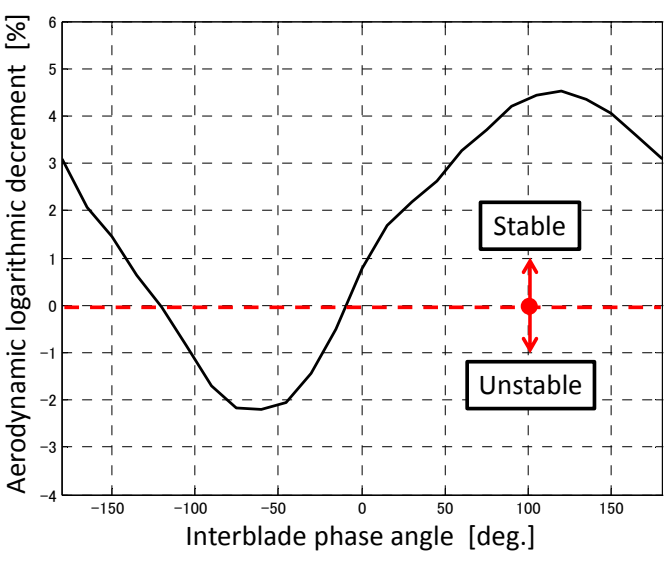

(b) Aerodynamic damping of tuned bladed disk

Fig. 1 Natural frequency and aerodynamic damping of tuned bladed disk. In the stability analysis of the actual bladed disk, the natural frequencies are estimated from calculated results of the similar bladed disk and the Campbell diagram described in the reference. Natural frequencies of the flexible disk and the stiff disk in Fig. 1(a) are used in the parametric study to research the effect of the structural coupling on the blade flutter. The aerodynamic damping extracted from the reference shows that some travelling wave modes are unstable. 


\section{3 -2 フラッタに対する交互ミスチューンの効果}

回転中の単独翼の振動数の平均值を $220 \mathrm{~Hz}$ と仮定し, 交互ミスチューンを与えて翼・ディスク系の安定性を解 析した結果を図 2 に示す. 交互ミスチューン系の解析では，奇数番目の翼の振動数を（平均值+ $\Delta f[\mathrm{~Hz}]$ ）に，偶 数番目の翼の振動数を（平均值一 $\Delta f[\mathrm{~Hz}]$ ）にしている. 図 2 の横軸は翼・ディスク系の 1 次モード族の固有振動 数であり，縦軸は減衰比（空力減衰）である。これから分るように，チューン系（図 2(a)）では多くの振動モー ドが不安定であるが，交互ミスチューンを与えると根軌跡は二つのグループに分離し，交互ミスチューンの量を 大きくしていくと，空力減衰の最小值は増加していく．その結果，図 2(c) に示すように， $\Delta f= \pm 5 \mathrm{~Hz}$ 程度の交互 ミスチューンを与えると, 全てのモードに対して空力減衰は正になり，翼・ディスク系は安定化される. 一方, 交互ミスチューンの量が大きくなると, 空力減衰の最大值は小さくなる. すなわち, 交互ミスチューンにより, 根軌跡は二つのグループに分離し，空力減衰の最小值は増加し，最大值は減少する．その結果，全てのモ一ドの 空力減衰の差が小さくなり，平均值に近づいていく.

文献 (日本機械学会編, 2010, Rust, et al., 1988, Nedeljkovic, et al., 1991) には，トラブルを発生したチタン翼の構 造減衰は対数減衰率で $1.78 \%$ （減衰比で $0.3 \%$ ）であり， $\pm 2.7 \mathrm{~Hz}$ の交互ミスチューンによりフラッタが防止でき たと説明されているが，図２の解析結果はこの事実と良く対応しており，2 章の解析方法の有効性が示されてい る.

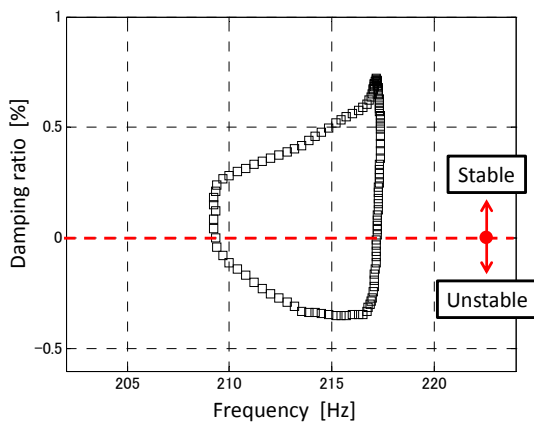

(a) Tuned bladed disk

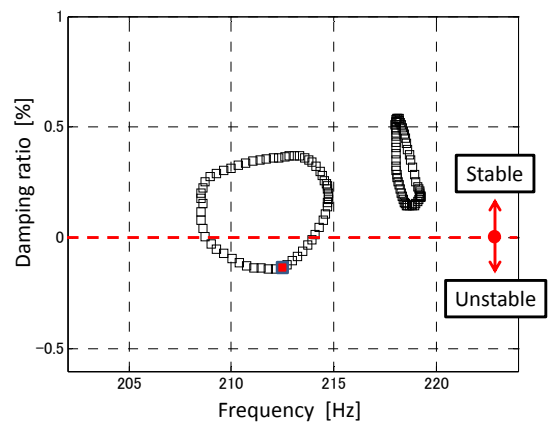

(b) Alternately mistuned $( \pm 2.5 \mathrm{~Hz})$

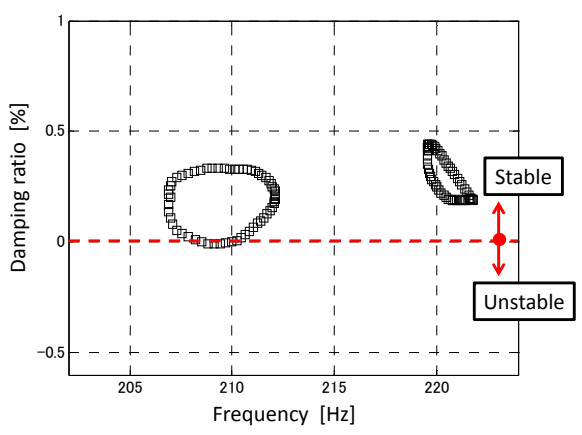

(c) Alternately mistuned $( \pm 5.0 \mathrm{~Hz})$

Fig. 2 Results of stability analysis of tuned and mistuned bladed disk with nominal disk. In the tuned bladed disk, which experienced the blade flutter, many travelling wave modes are unstable. The stability map of the mistuned bladed disk is divided into two parts by the alternate mistuning. With increase of the alternate mistuning, the minimum damping increases, and almost all modes become stable when the alternate mistuning increases up to $\pm 5 \mathrm{~Hz}$. On the other hand, maximum aerodynamic damping decreases with increase of the alternate mistuning. In other words, difference between the maximum and minimum aerodynamic damping decreases by the alternate mistuning.

図 3(a) は，交互ミスチューンがさ2.5Hz のときに減衰が最小になる振動モード（図 2(b)の赤印）の振幅分布を 示しており，図 3(b) はこのモードでフラッタに突入したときに各翼に発生する振幅分布を示している. 図 3(a) より減衰が最小の振動モードの節直径数は 13 であることが読み取れ, 交互ミスチューン系においてもチューン系 で減衰が最小になる翼間位相差（図 2(b)）に近いモードが不安定になることが示されている．また，図 3(b) に示 すように, フラッタ突入時には振動数が低い翼の振幅が大きくなっている. すなわち, 交互ミスチューン系では, 振動数が低いグループの振動モードでフラッタに突入すると振動数の低い翼の振幅が大きくなり，振動数が高い グループの振動モードでフラッタに突入すると振動数の高い翼の振幅が大きくなる.

図 4 と図 5 は，構造連成の強さが安定性に及ぼす影響を検討するため，ディスクの形状（剛性）だけを変化さ せて安定性解析を行った結果を示している. 図 4 はディスクが薄く構造連成が強い場合（図 1(a) の Flexibleディ スク）の安定性解析結果であり，図 1(a) に示すように，チューン系の 1 次モード族の固有振動数の差（0 節直径 モードと 60 節直径モードの振動数の差) は約 $15 \mathrm{~Hz}$ である. 一方, 図 5 はディスクが厚く構造連成が弱い場合 (図 1(a) の Stiffディスク) の安定性解析結果であり, チューン系の 1 次モード族の固有振動数の差は約 $2 \mathrm{~Hz}$ になって いる. 
図 2, 図 4，および図 5 の比較から分るように，チューン系に対する空力減衰の大きさは，構造連成の強さ（デ イスク剛性の大きさ）を変化させてもほとんど変化しない．これに対してミスチューン系では安定性に対する構 造連成の影響が大きく現われており，ディスク連成が強い翼・ディスク系では， $\pm 5 \mathrm{~Hz}$ の交互ミスチューンを与 えても空力減衰が負になるモードが存在している（図 4). 一方，図 5 に示すように，ディスク連成が弱い翼・デ イスク系では， $\pm 2.5 \mathrm{~Hz}$ の交互ミスチューンにより全てのモードが安定化されている. 寸なわち，構造連成の強 さは安定性に大きな影響を及ぼしており，構造連成が強い翼・ディスク系ほどミスチューンによりフラッタを防 止することが困難になることが示されている.

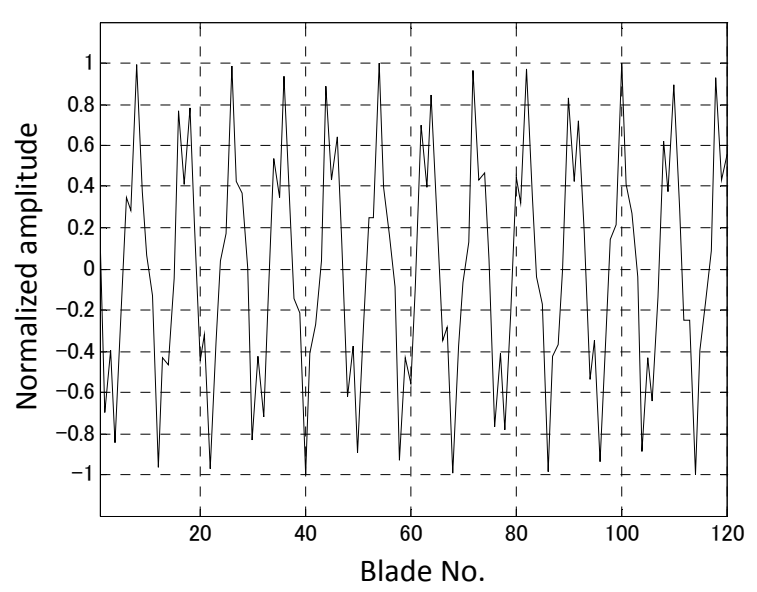

(a) Vibration mode with minimum damping

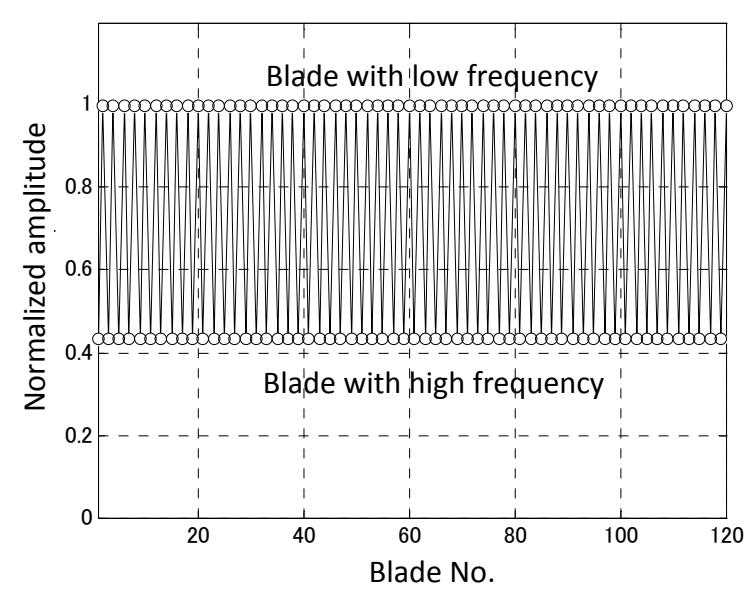

(b) Amplitude distribution with minimum damping

Fig. 3 Vibration mode and flutter amplitude with minimum damping (Alternate mistuning $\pm 2.5 \mathrm{~Hz}$ ). The vibration mode with the minimum damping is 13 nodal diameters mode. The flutter of the mistuned bladed disk occurs in the nearly same modes as that of the tuned bladed disk. In the flutter of the bladed disk with the alternate mistuning, the blades with the large amplitude and the blade with the small amplitude appear alternatively. Namely, in the bladed disk with the alternate mistuning, when the flutter occurs in the vibration mode belonging to the low frequency group, the amplitude of the blades with the low frequency becomes large.

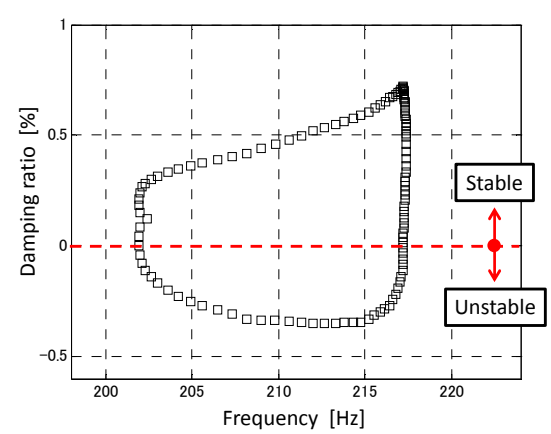

(a) Tuned bladed disk

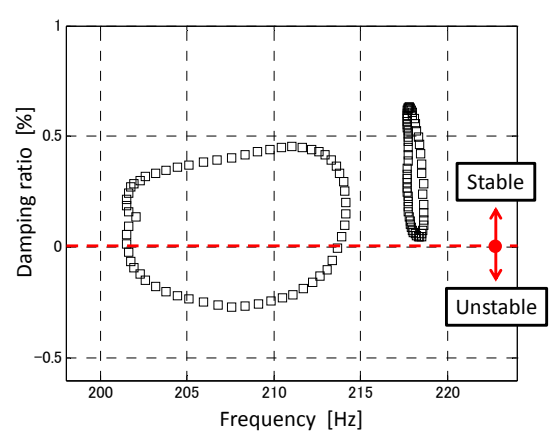

(b) Alternately mistuned $( \pm 2.5 \mathrm{~Hz})$

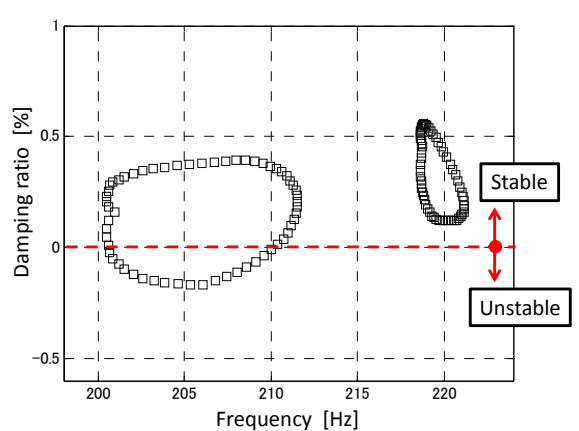

(c) Alternately mistuned $( \pm 5.0 \mathrm{~Hz})$

Fig. 4 Results of stability analysis of tuned and mistuned bladed disk with flexible disk. The aerodynamic damping of the tuned bladed disk with the flexible disk is the nearly same as that with the nominal disk. However, in the mistuned bladed disk with the flexible disk, even if the alternate mistuning increases up to $\pm 5.0 \mathrm{~Hz}$, some travelling wave modes are still unstable. In other words, if the structural coupling of the bladed disk is strong, it is difficult to stabilize the unstable vibration modes by the alternate mistuning. 


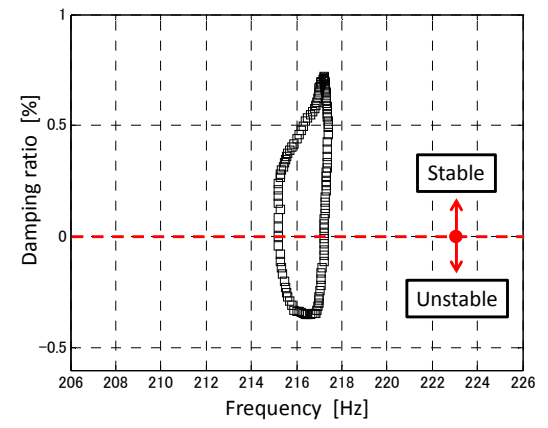

(a) Tuned bladed disk

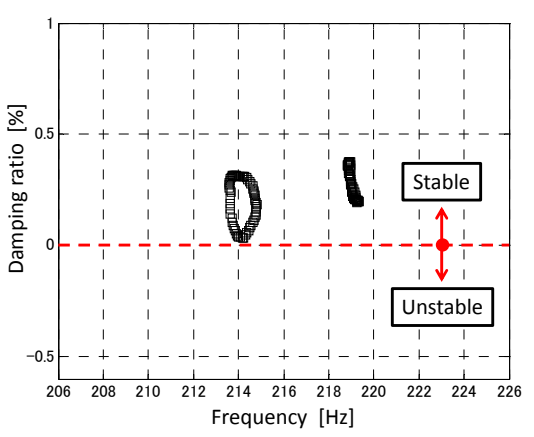

(b) Alternately mistuned $( \pm 2.5 \mathrm{~Hz})$

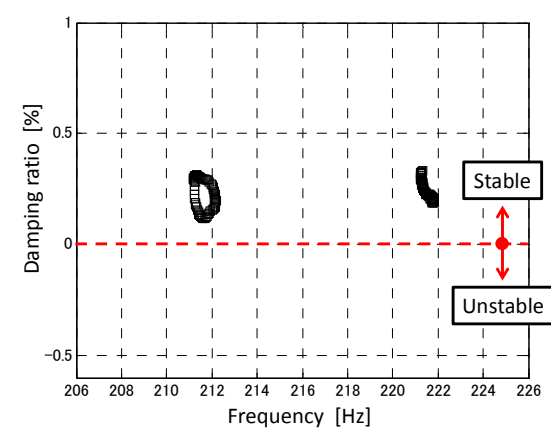

(c) Alternately mistuned $( \pm 5.0 \mathrm{~Hz})$

Fig. 5 Results of stability analysis of tuned and mistuned bladed disk with stiff disk. The aerodynamic damping of the tuned bladed disk with the stiff disk is the nearly same as that with the nominal disk. However, in the mistuned bladed disk with the stiff disk, only if the alternate mistuning increases up to $\pm 2.5 \mathrm{~Hz}$, all travelling wave modes are stabilized. In other words, if the structural coupling of the bladed disk is weak, it is easy to stabilize the unstable vibration modes by the alternate mistuning.

\section{$3 \cdot 3$ フラッタに対するランダムミスチューンの効果}

現実の翼・ディスク系では単独翼の固有振動数はランダムに分布していると考えられるため,ディスク上の個々 の翼の振動数をランダムに分布させて安定性解析を行った. ランダムミスチューン系の解析では, 単独翼の固有 振動数は正規分布に従うと仮定し, 与えた正規分布から翼振動数をランダムに抽出して翼・ディスク系を組立て,

2 章に述べた方法で空力減衰を求めた.

図 6 と図 7 はランダムミスチューン系の安定性の解析例であり，図 6 は単独翼固有振動数の標準偏差が $1 \%$ の ときの単独翼振動数の分布と安定性解析結果を, 図 7 は単独翼固有振動数の標準偏差が $3 \%$ ときの単独翼振動 数の分布と安定性解析結果を示している. ランダムに単独翼固有振動数を変化させると，根軌跡もランダムに変 動しており，この例では，単独翼固有振動数の標準偏差が $3 \%$ こると，全てのモードは安定になることが示さ れている. また図2(a)と図6(b), 図7(b) の比較から分るように, ランダムミスチューンの影響は, 単独翼振動数 の標準偏差が小さい場合は振動数が高い高次の節直径モード, すなわち図 1(a) において節直径数に対する固有振 動数の勾配が小さいモードに対して大きく現われる（図 6(b)). 単独翼振動数の標準偏差が大きくなると，全ての 節直径モードに対してミスチューンの影響が現われるようになり，減衰の最大值と最小值の差が小さくなり，結 果的に全てのモードの減衰は正になり安定になる（図 7(b)).

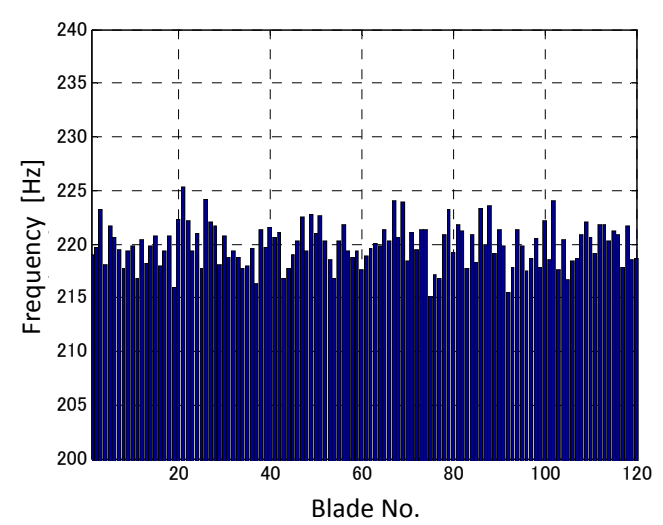

(a) Frequency distribution

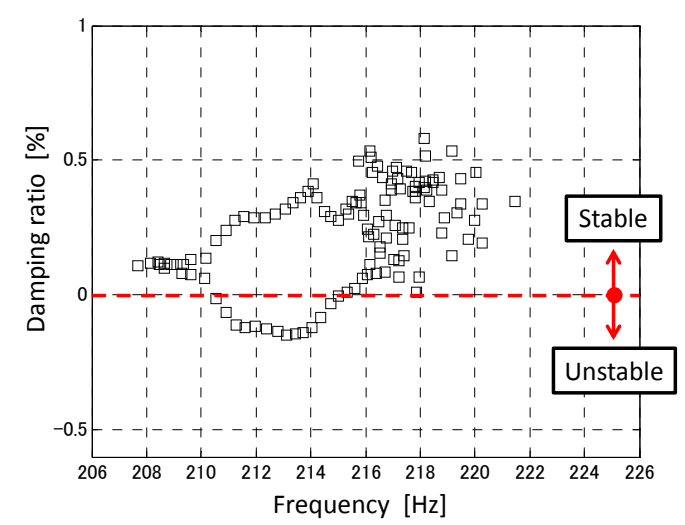

(b) Natural frequency and damping

Fig. 6 Stability of random mistuned bladed disk (Nominal disk, Standard deviation of freestanding blade, $\sigma_{f}=1 \%$ ). If the random mistuning is given on a bladed disk, the root locus of a tuned bladed disk fluctuates at random, and the minimum aerodynamic damping increases. If the random mistuning is small, the roots corresponding to the vibration modes with many nodal diameters, first, fluctuate remarkably. 


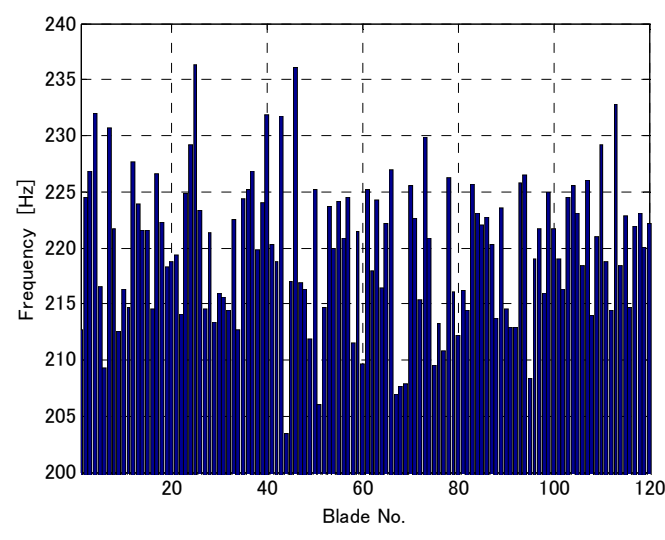

(a) Frequency distribution

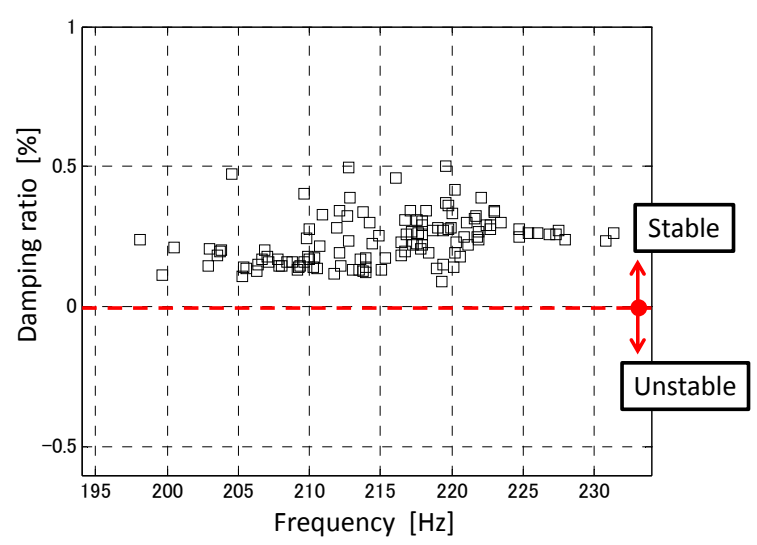

(b) Natural frequency and damping

Fig. 7 Stability of random mistuned bladed disk (Nominal disk, Standard deviation of freestanding blade, $\sigma_{f}=3 \%$ ). If the random mistuning given on a bladed disk becomes large, all roots of a tuned bladed disk fluctuate remarkably. If the standard deviation of freestanding blade increases up to 3\%, all unstable modes of the tuned bladed disk are stabilized.

図 8 は, モンテカルロ法により単独翼振動数の標準偏差をパラメータにして 1000 個の翼・ディスク系の安定性 解析を行い，1000 個の翼・ディスク系の最小の減衰比について確率分布を計算した結果を示している. これから 分るように，単独翼振動数の標準偏差が $1 \%$ 以下の場合には全ての翼・ディスク系の減衰は負であり不安定であ るが，2\%以上にするとほとんどの翼・ディスク系の減衰が正になり，安定になる．また，これ以上単独翼振動数 の標準偏差を大きくしても，安定性は大きく改善されないことが示されている.

実際にフラッタが発生した翼・ディスク系の単独翼振動数の標準偏差は文献に記載されていないが，通常， 単独翼固有振動数のばらつきは標準偏差で $0.5 \%$ 1\%程度と予想される．従って，材料定数や工作誤差によるミ スチューンだけでは構造減衰の影響を考慮してもトータルの減衰が負になり，フラッタが発生したものと解釈で きる.

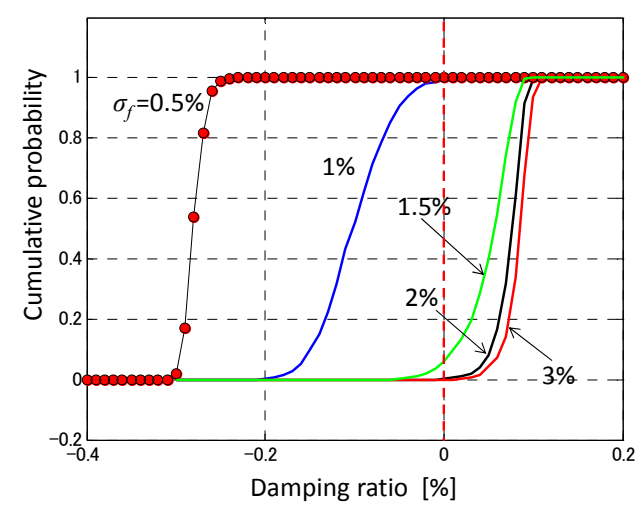

Fig. 8 Probability of damping ratio of bladed disk with random mistuning (Nominal disk). If the random mistuning given on a bladed disk becomes large, the minimum damping ratio of a bladed disk increases. When the standard deviation of freestanding blade is $1 \%$, the minimum damping ratios of all bladed disks are negative, and unstable. However, if the standard deviation of freestanding blade increases up to $2 \%$, all bladed disks are stabilized. Furthermore, even if the standard deviation of freestanding blade increases beyond $2 \%$, stability is not improved remarkably.

図 9 と図 10 は, ランダムミスチューン系に対して構造連成の強さが安定性に及ぼす影響を検討するため, ディ スクの形状 (岡性) だけを図 1(a) の Flexible ディスクに変化させて安定性解析を行った結果を示している. 図 9 は単独翼固有振動数の標準偏差が $1 \%$ のきの単独翼振動数の分布と安定性解析結果を, 図 10 は単独翼固有振動 数の標準偏差が 3\%のときの単独翼振動数の分布と安定性解析結果を示している. Flexible ディスクの場合も, 単 独翼固有振動数の標準偏差が $1 \%$ のとき不安定であるが (図 9(b))，3\%にすると全てのモードは安定になること 
が示されている (図 10(b))。また, Flexibleディスクの場合も Nominal ディスクの場合と同様に, ランダムミスチ ユーンの影響は，単独翼振動数の標準偏差が小さい場合は振動数が高い高次の節直径モードに対して大きく現わ れる (図 9(b)). 単独翼振動数の標準偏差が大きくなると，全ての節直径モードに対してミスチューンの影響が現 われるようになり，減衰の最大值と最小值の差が小さくなり，結果的に全てのモードの減衰は正になり安定にな る(図 10(b)).

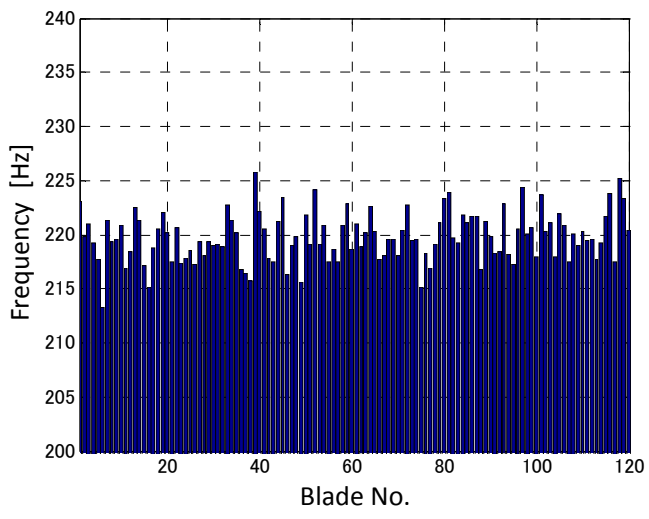

(a) Frequency distribution

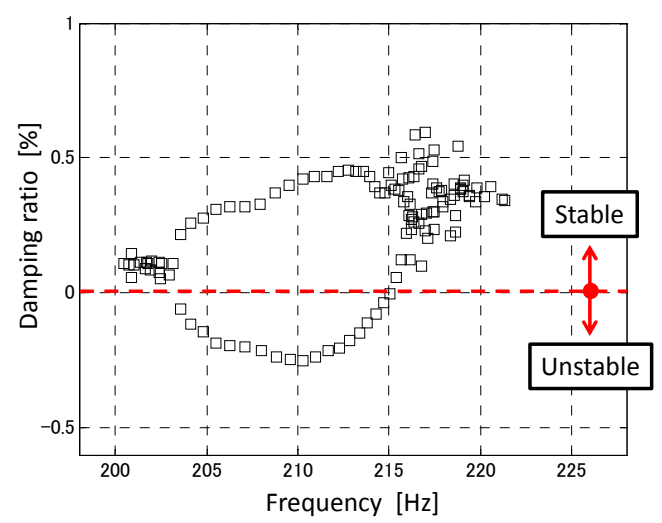

(b) Natural frequency and damping

Fig. 9 Stability of random mistuned bladed disk (Flexible disk, Standard deviation of freestanding blade, $\sigma_{f}=1 \%$ ). If the random mistuning is given on a bladed disk, the roots corresponding to the vibration modes with many nodal diameters fluctuate remarkably as well as a bladed disk with the nominal disk. However, comparing Fig 9(b) with the nominal disk (Fig. 6(b)), it is said that the fluctuation of roots of the flexible disk are smaller than that of the nominal disk.

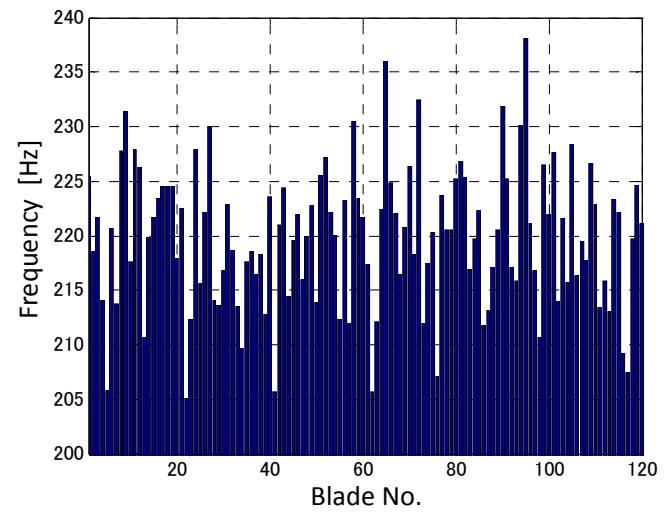

(a) Frequency distribution

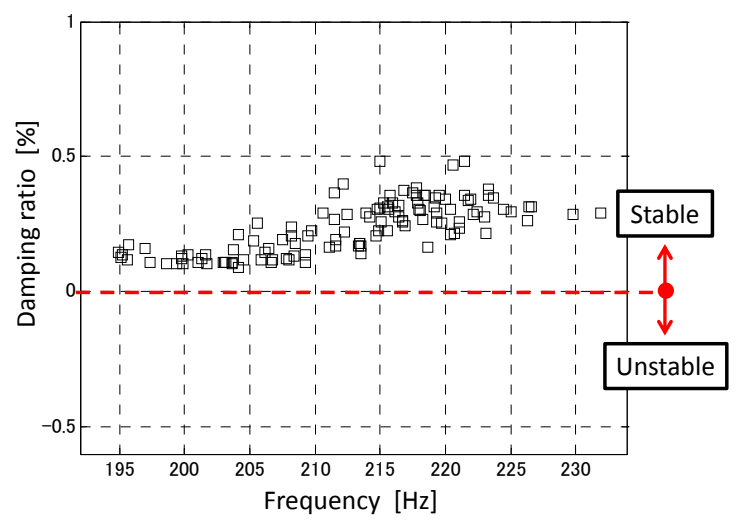

(b) Natural frequency and damping

Fig. 10 Stability of random mistuned bladed disk (Flexible disk, Standard deviation of freestanding blade, $\sigma_{f}=3 \%$ ). If the random mistuning given on a bladed disk becomes large, all roots of a tuned bladed disk fluctuate remarkably. If the standard deviation of freestanding blade increases up to 3\%, all unstable modes of the tuned bladed disk are stabilized as well as the nominal disk..

図 11 は，ディスクの剛性が小さい Flexibleディスクの翼・ディスク系に対してモンテカルロ法により安定性解 析を行った結果である.ここでも図 8 と同様に, 単独翼振動数の標準偏差をパラメータにして 1000 個の翼・ディ スク系について安定性解析を行い，1000 個の翼・ディスク系の最小の減衰比の確率分布を求めている. 図 8 と図 11 の比較から分るように, Nominal ディスクの場合は単独翼振動数の標準偏差が $2 \%$ 以になるとほとんどの翼・ ディスク系の減衰が正になるのに対して, Flexible ディスクの場合は単独翼振動数の標準偏差を $3 \%$ 以上にしなけ

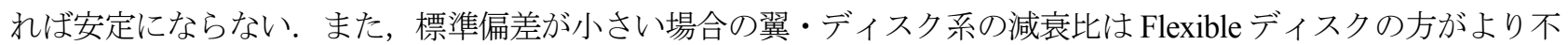


安定側になっている．すなわちランダムミスチューンの場合も構造連成の強さが安定性に大きな影響を及ぼして おり，構造連成が強い翼・ディスク系ほどミスチューンによりフラッタを防止することが困難になることが示さ れている.

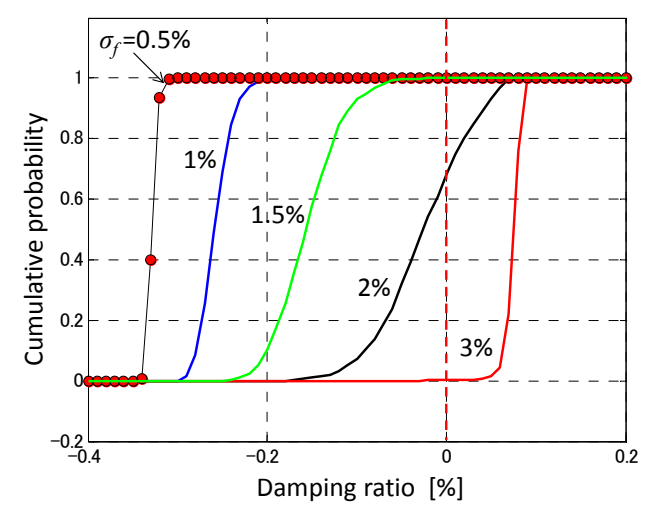

Fig. 11 Probability of damping ratio of bladed disk with random mistuning (Flexible disk). When the standard deviation of freestanding blade is $1.5 \%$, the minimum damping ratios of all bladed disks are negative, and unstable. However, if the standard deviation of freestanding blade increases up to 3\%, all bladed disks are stabilized. Comparing Fig. 8 with Fig. 11 , it is said that if the structural coupling of the bladed disk is weak, it is easy to stabilize the unstable vibration modes by the random mistuning.

\section{$3 \cdot 4$ フラッタに対する翼材料変更の効果}

フラッタが発生したチタン L-1R 翼は, 元々，スチール翼であったが，乾湿交番域の腐食防止対策として，翼 材料を耐食性に優れたチタンに変更している．また，オリジナルのスチール翼にフラッタは発生していない．こ の原因を調査するため，スチール翼のランダムミスチューン系に対して安定性解析を行った．スチール翼の安定 性解析では，チタンとスチールでは弾性係数と密度の比はほぼ同一であるため，振動数や振動モードは同一と仮 定している．また，モーダル質量で無次元化されたチタン翼に対する非定常力（図 1(b)）を密度比で補正してス チール翼の非定常力を求めている.

図 12 は，スチール翼の翼・ディスク系（Nominal ディスク）に対してモンテカルロ法により安定性解析を行 った結果である. 図 8 と図 12 の比較から分るように, スチール翼の方がチタン翼よりも安定であり, スチール翼 の場合は単独翼振動数の標準偏差が $1.5 \%$ 程度になると, 全ての翼・ディスク系は安定になることが示されている. スチール翼の場合も, 単独翼固有振動数のばらつきは標準偏差で $0.5 \%$ \% 程度と予想される. 従って, 構造減 衰の影響を考慮すれば，材料定数や工作誤差によるランダムミスチューンによりフラッタの発生を防止できてい たと解釈できる. 


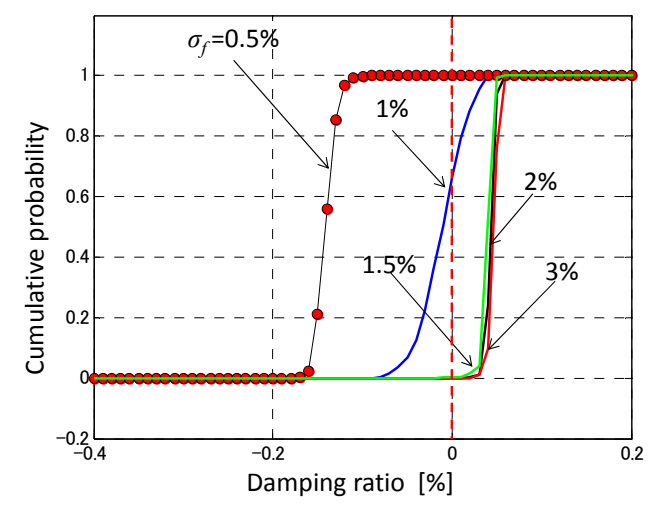

Fig. 12 Probability of damping ratio of bladed disk with random mistuning (Nominal disk, Steel blade). The stability of the steel blade is superior to the titanium blade. If the standard deviation of freestanding blade increases up to $1.5 \%$, all bladed disks are stabilized.

\section{4. 結 論}

本研究では低次元モデル FMM を利用した安定性解析法を適用して，実際にフラッタが発生した蒸気タービン の翼・ディスク系の逆解析を行った。ささに，ミスチューニングのパターンや強さ，ディスクの連成効果（構造 連成の強さ), 翼材料などについてパラメータスタディを行い, フラッタに対するミスチューニングの効果を調査 した。その結果，以下の結論が得られた。

（1）トラブルを発生した蒸気タービン L-1Rのフラッタが，交互ミスチューンにより防止できたこと，オリ ジナルのスチール翼ではフラッタが発生していないことなどを解析により定量的に説明することができており， FMM を利用した安定性解析法の妥当性が検証できた.

（2）交互ミスチューンやランダムミスチューンが翼・ディスク系の安定性に及ぼす影響を明確にすることが できた.

\section{文献}

Bendiksen, O. O., Flutter of mistuned turbomachinery rotor, ASME Journal of Engineering for Gas Turbines and Power, No. 106 (1984),pp.25-33.

Carlos, M., Roque, C. and Jose, M. L., Stability increase of aerodynamically unstable rotors using intentional mistuning, ASME Journal of Turbomachinery, Vol. 130, 011006 (2008), pp.1-10.

Feiner, D. M. and Griffin, J. H., A fundamental model of mistuning for a single family of modes, ASME, Journal of Turbomachinery, Vol.124 (2002), pp.597-605.

Feiner, D. M. and Griffin, J. H., Mistuning identification of bladed disks using a fundamental mistuning model-part 1: theory, Proceedings of ASME Turbo Expo 2003, GT2003-38952 (2003), pp.1-10.

金子康智，間瀬正隆，藤田勝久，長嶋利夫，ミスチューンがある翼・ディスク系の応答解析，日本機械学会論文 集 C 編, Vol.58, No.547 (1992), pp.744-749.

Kaza, K. R. V. and Kielb, R. E., Flutter and response of a mistuned cascade in incompressible flow, AIAA Journal, Vol. 20, No. 8 (1982), pp.1120-1127.

Kielb, R. E., Feiner, D. M., Griffin, J. H. and Miyakozawa, T., Flutter of mistuned bladed disks and blisks with aerodynamic and FMM structural coupling, Proceedings of ASME Turbo Expo 2004, GT2004-54315 (2004), pp.1-7. 
Kielb, R. E., Hall, K. C. and Miyakozawa, T., The effect of unsteady aerodynamic asymmetric perturbations on flutter, Proceedings of ASME Turbo Expo 2007, GT2007-27503 (2007), pp.1-6.

Nedeljkovic, S. I., Rozelle, P. F. and Seth, B. B., Design and verification of mixed-tuned titanium freestanding low pressure steam turbine blades, ASME Pwr-Vol. 13 (1991), pp.203-208.

Rust, T. M, Seth, B. B. and Thompson, T. L., Application of titanium to low pressure transition stage steam turbine blading at Tu Electric, EPRI ER-6538 Workshop Proceeding (1988), pp.171-213.

日本機械学会編，v-Base データベース，蒸気タービンチタン単独翼のフラッタ，Data-No. 95-1-2 (2010), pp.6-7.

\section{References}

Bendiksen, O. O., Flutter of mistuned turbomachinery rotor, ASME Journal of Engineering for Gas Turbines and Power, No. 106 (1984),pp.25-33.

Carlos, M., Roque C. and Jose, M. L., Stability increase of aerodynamically unstable rotors using intentional mistuning, ASME Journal of Turbomachinery, Vol. 130, 011006 (2008), pp.1-10.

Feiner, D. M. and Griffin, J. H., A fundamental model of mistuning for a single family of modes, ASME, Journal of Turbomachinery, Vol.124 (2002), pp.597-605.

Feiner, D. M. and Griffin, J. H., Mistuning identification of bladed disks using a fundamental mistuning model-part 1: theory, Proceedings of ASME Turbo Expo 2003, GT2003-38952 (2003), pp.1-10.

Kaneko, Y., Mase, M., Fujita, K. and Nagashima, T., Vibration response analysis of mistuned bladed disk, Transactions of the Japan Society of Mechanical Engineers, Series C, Vol. 58, No. 547 (1992), pp.744-749(in Japanese).

Kaza, K. R. V. and Kielb, R. E., Flutter and response of a mistuned cascade in incompressible flow, AIAA Journal, Vol. 20, No. 8 (1982), pp.1120-1127.

Kielb, R. E., Feiner, D. M., Griffin, J. H. and Miyakozawa, T., Flutter of mistuned bladed disks and blisks with aerodynamic and FMM structural coupling, Proceedings of ASME Turbo Expo 2004, GT2004-54315 (2004), pp.1-7.

Kielb, R. E., Hall, K. C. and Miyakozawa, T., The effect of unsteady aerodynamic asymmetric perturbations on flutter, Proceedings of ASME Turbo Expo 2007, GT2007-27503 (2007), pp.1-6.

Nedeljkovic, S. I., Rozelle, P. F. and Seth, B. B., Design and verification of mixed-tuned titanium freestanding low pressure steam turbine blades, ASME Pwr-Vol. 13 (1991), pp.203-208.

Rust, T. M, Seth, B. B. and Thompson, T. L., Application of titanium to low pressure transition stage steam turbine blading at Tu Electric, EPRI ER-6538 Workshop Proceeding (1988), pp.171-213.

The Japan Society of Mechanical Engineers ed., v-Base Database, Flutter of steam turbine titanium freestanding blade, Data-No. 95-1-2 (2010), pp.6-7 (in Japanese). 